\title{
A Study On The Use Of Shipping Container Booth As A Substitution Of Street Vendors Cart
}

\author{
Nurhayatu Nufut Alimin1, Fidyani Samantha2, Mulyadi3, Ahmad Faizin4 \\ 1, 2, 3, 4 Department of Interior Design, Faculty of Art and Design, Sebelas Maret University, Jl. Ir Sutami \\ No.36A, Surakarta, 57126, Indonesia \\ Email korespondensi: nurhayatunufut@staff.uns.ac.id
}

Received 28 March 2021, Revised 28 May 2021, Accepted 31 May 2021

\begin{abstract}
The present study focused on the development of a compact living concept that is applied in commercial facilities, especially shipping container-booth. This study aimed to investigate the organization of container booths in Solo area from interior design perspectives, including its visual aesthetics, visual brand identity, and space function and organization of the container booth. The result of the study may depict the advantages of container booths, compared to conventional street food carts. This study was expected to provide adequate data to establish a new revenue-generating unit. To this end, a qualitative descriptive method was applied to obtain in-depth data related to the exterior and interior aspects of the booth. This study showed that container booth holds some advantages related to visual aesthetic aspects since it could be easily added with aesthetic elements for promotion media. Container booth also allows a division of area that supports the seller's activity.
\end{abstract}

Keywords: Container booth; Street food vendor, Interior Design

\section{INTRODUCTION}

One of the problems faced by the Indonesian government is related to urban planning. In this regard, one of the problems is associated with the arrangement of street food vendors. On one hand, these street vendors decrease unemployment. On the other hand, their existence disturbs other people's activities since they do their business on sidewalks, a public space that is supposed to be free from buildings and any commercial activity.

To cope with this issue, Jakarta government tried to apply a solution through its "Sidewalk Revitalization" program. This program, officially announced by Jakarta Governor, sees street vendors as a part of the sidewalk. This program originates from Public Work and Housing Minister Regulation no. 3 of 2014 on Guidelines of Provision and Use of Pedestrian Facilities in Urban Area (Setiyaningsih, Wahidin: 2019). The core idea of this program is to divide sidewalks with certain widths into two sections, pedestrian track, and street vendors space. This program is deemed as a solution for spatial planning issue that is integrated with the development of the micro economy. A similar solution has been applied in New York City, where street vendors have been a part of the city icon. In Makassar city, the government built 216 booths from shipping containers to substitute conventional street food carts (Eggi Septianto, Handoyo Dwi P., Arief Rahman H. 2015).

Recently in Solo area, many street food vendors begin to use container booths, as shown on sidewalks behind UNS area. This fact shows that street vendors prefer to use a shipping container booth than a wood cart to attract customers who are mostly university students. The present study investigated the advantages of a shipping container as a medium to sell foods and aimed to find out the ideal form of the booth from interior design perspective.

Some previous studies have investigated the use of a shipping container as an alternative building material. However, most of these studies discuss shipping container as a building material for residential purposes and public functions. (Eggi Septianto, Handoyo Dwi P., Arief Rahman H. 2015) Studies the use of a shipping container for Dental treatment facility and public library in Malang. Meanwhile (Putra 2016) examines the use of a shipping container as a temporary disaster relief shelter. (Maria Valenciana Utari Prajogo and Purnama E.D. Tedjokoesoemo 2015) Studies the interior design of container for educational means in Rusun Sombo Surabaya. To date, there is no scholarly article that reports the use of a shipping container for street food vendor booths.

Despite the importance of urban planning issues related to street food vendor arrangement, studies on the use of a shipping container as the main material to build street food vendor booth have never been reported. Accordingly, the present study is important to solve the problems faced by the 
community related to urban planning. As the first step, the present study is limited to the Solo area.

\section{RESEARCH METHODOLOGY}

In the present study, container-booth was viewed as a product to fulfill human needs. The design of the booth constitutes a composition of design elements. Accordingly, two stages were applied. The first stage involved an analysis of functionality and the problem-solving aspects. The second stage involved an analysis of visual elements using an aesthetic approach. This study employed a descriptive analytical method that emphasized the function and formal aspects.

\section{Data Collection Method}

Authentic, real data were obtained through a field survey. It was done by taking pictures, measuring booths, and conducting interviews with peoples related to the topic of this study. The primary data were collected in locations around Surakarta city where commercial activities using container-booth took place. The observation was done to describe the actors, activities, facilities, functions, and other factors related to the container booth. The result of the observation was used as a guideline in the analysis process of the external form and function of the container booth. Moreover, interviews were also conducted with the owners of the container booth. A literature study related to container booths was also conducted.

\section{Data Analysis}

In the data analysis stage, we analyze the container-booth from interior design aspects, which is divided into two sections, namely the analysis of visual aesthetic and visual brand identity aspects and analysis of space functions and organizations of the container-booth. The analysis result showed the visual role in product branding and the spatial organization to support the activities within the container booth.

\section{RESULTS AND DISCUSSION}

The concept of compact living has been a popular housing concept in the world. People's high demands on housing face problems related to limited land availability, resulting in the emergence of house design models with the compact living concept, a house with flexible, multifunction furniture to optimize space use and activities. This concept allows maximum use of spaces and furniture, meaning that all furniture holds real functions to support the owners' activities, not merely a decoration. This concept aims to provide more space and circulation (Hamsa, 2016). In addition to efficiency, innovations in this design concept are necessary to win property market competition (Andyna. 2015).
Container-booth is the development of the compact living concept for more flexible, movable space for commercial purposes. This compact street vendor concept utilizes and modifies a shipping container to make it interesting and proper to use. (Hignasari and Mahira 2018). Today, many innovations are made by utilizing shipping containers, one of the innovations is in the form of the booth.

Shipping container becomes the first choice in building compact housing or booth due to their robust structure, shock-resistant, recyclable, and easy-to-move features (Hignasari and Mahira 2018). Malcolm McLean is the holder of the patent of shipping container. House container should be robust, inexpensive, and efficient to save more money and time. Afterward, in 1987, Phillip C. Lark explained a method how to transform a shipping container into a livable building. The advantages of shipping container include robust structure, inexpensive, earthquake resistant, flexible, and waste reduction (Norris, Brodie, 2015).

In the present study, we focused on street food vendor container booth as this type of street food vendor begins to gain popularity among the street vendors in Surakarta. Ten booths around Surakarta area were analyzed. They belong to Cireng Ginueq (Jebres), Kebab Turki (Nusukan), Mimasoyong (Jebres), Staykult (Jebres), Banris (Purwosari), Kebab Tunisia (Slamet Riyadi), Kue Balok Parikesit (Penumping), Martabak Atria (Keprbon), Milenial Kopi (Kartasura), and Teh Poci (Jebres).

The first booth was Cireng Ginueq's booth, this is a container booth selling various westjavanese traditional food known as cireng, it was located in Jalan Kartika no. 35, Jebres Sub-district, Surakarta City, Central Java. The second both was Kebab Turki Baba Rafi, a booth selling various types of kebab locating in Nusukan, Banjarsari subdistrict, Surakarta City, Central Java. The third booth was Mimasoyong; this booth sells various types of instant noodle. Its tagline reads "Mie Kesukaan, Mie Masoyong". Mimasoyong is the abbreviation of Mie Masoyong. The fourth booth was Staykult, a booth selling various types of drink made of Yakult. This booth was located in Jebres, Surakarta, Central Java. (6) The fifth booth was Banris, a booth selling a crispy fried banana with various toppings such as chocolate, peanut, cheese, greentea, etc. This booth was located in Jalan Hasanuddin, Purwosari, Laweyan sub-district, Surakarta. (6) The sixth booth was Kebab Tunisia, similar to Kebab Turki Baba Rafi, this booth sold various kebab menus. It was located in Jalan Slamet Riyadi no. 125, Surakarta. (7) The seventh booth was Kue Balok Parikesit, located in Jalan Kebangkitan Nasional no. 53, Laweyan, Surakarta this booth sell fudgy brownies. (8) The eighth booth was Martabak Atria, this booth sells various types of sweet and salted martabak with various 
toppings. This booth was located in Jalan Ronggowarsito no. 113, Jati, Keprabon, Banjarsari subdistrict, Surakarta. (9) The ninth booth was Milenial Kopi. This booth sells various types of coffees. It was located in Jalan Slamet Riyadi no. 216A, Gumpang, Kartasura, Sukoharjo. (10) The tenth booth was Teh Poci Express, a franchise of Teh Poci brands. Located in Jalan Ki Hajar Dewantara no. 51, Jebres, Surakarta, this booth sells various types of tea.

These container booths have different characteristics in accordance with their needs and the product they sell. Three main aspects of these booths were analyzed, including the visual aspects (i.e., form, color, and visual identity), function, and comfortability aspects.

\section{Visual Aesthetic and Visual Brand Identity Analysis}

The first analysis was focused on the visual aspect of the selected booths. Since visual is the main value a person's eyes can capture, this is one of the most crucial aspects of a product. In the field of visual art, humans use their senses to consider whether or not an object is aesthetic. In this study, the aesthetics of the booth is viewed from the formal aspects. Accordingly, this study viewed the physical aspect of the container booths that exhibit certain forms and elements (Suryajaya, 2016). The physical formal aspects of the booth were associated with the visual identity aspect to see whether or not the visual form of the booth represents the identity of the product.

The analysis of visual aspects of the booth included the form, color, and visual identity.

Table 1 Analysis of appearance related to openings and visual identity

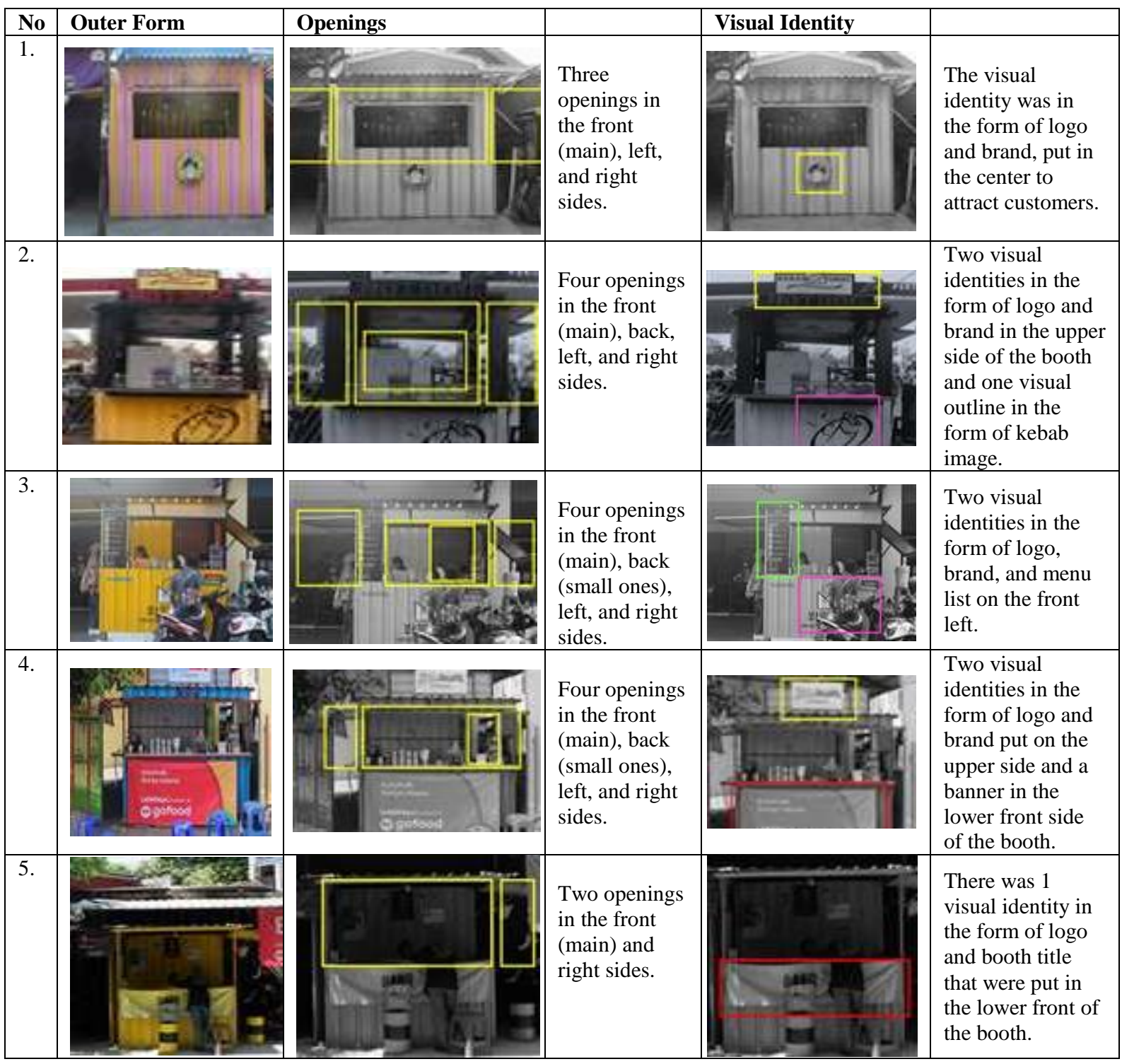




\begin{tabular}{|c|c|c|c|c|c|}
\hline 6. &  & 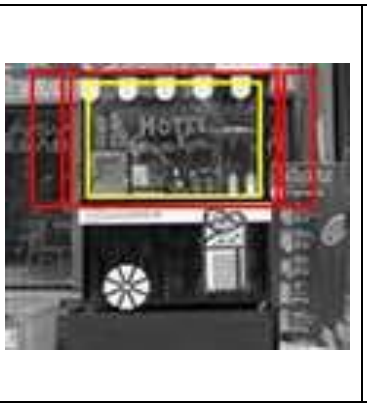 & $\begin{array}{l}\text { There were } \\
\text { three glass } \\
\text { openings in } \\
\text { the front } \\
\text { (main), right } \\
\text { and left sides, } \\
\text { and } 1 \text { opening } \\
\text { at the back. }\end{array}$ & 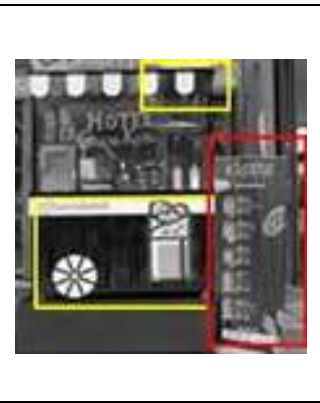 & $\begin{array}{l}\text { There were three } \\
\text { visual identities } \\
\text { in the form of } \\
\text { booth title (put on } \\
\text { the upper side of } \\
\text { the booth, kebab } \\
\text { illustration on the } \\
\text { front side, and } \\
\text { menu list in the } \\
\text { right front side of } \\
\text { the booth. }\end{array}$ \\
\hline 7. & UB: & 4 & $\begin{array}{l}\text { Two openings } \\
\text { in the front } \\
\text { (main) and } \\
\text { right sides. }\end{array}$ & kulay & $\begin{array}{l}\text { There were two } \\
\text { visual identities } \\
\text { in the form of } \\
\text { logo and title that } \\
\text { were put inside } \\
\text { the booth (visible } \\
\text { when the booth is } \\
\text { opened) and a } \\
\text { logo and title } \\
\text { banner that was } \\
\text { put on the lower } \\
\text { front of the booth. }\end{array}$ \\
\hline 8. & 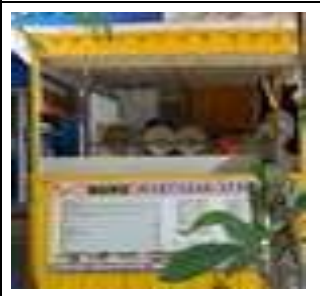 & 5 & $\begin{array}{l}\text { There were } \\
\text { three } \\
\text { openings, in } \\
\text { the front } \\
\text { (main), left, } \\
\text { and right } \\
\text { sides. }\end{array}$ & 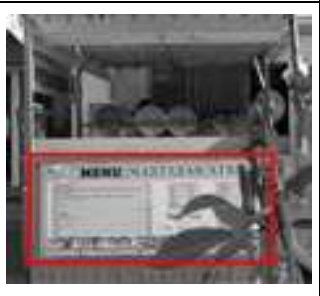 & $\begin{array}{l}\text { There was } 1 \\
\text { visual identity in } \\
\text { the form of title, } \\
\text { logo, and menu } \\
\text { banner that was } \\
\text { put in the lower } \\
\text { front of the booth. }\end{array}$ \\
\hline 9. & & & $\begin{array}{l}\text { There were } \\
\text { two small } \\
\text { direct } \\
\text { openings in } \\
\text { the front and } \\
\text { the left sides, } \\
\text { and glass } \\
\text { openings in } \\
\text { the front } \\
\text { (main) and the } \\
\text { left sides. }\end{array}$ & $=$ & $\begin{array}{l}\text { There was one } \\
\text { visual identity in } \\
\text { the form of logo } \\
\text { and title of the } \\
\text { booth on the front } \\
\text { glass openings. }\end{array}$ \\
\hline 10 & 1 exese 1 & E. & $\begin{array}{l}\text { There were } \\
\text { two openings } \\
\text { in the front } \\
\text { (main) and } \\
\text { right sides. }\end{array}$ & $\frac{5 i}{2}$ & $\begin{array}{l}\text { There were three } \\
\text { visual identities } \\
\text { in the form of } \\
\text { title and logo } \\
\text { (upper side), tea } \\
\text { illustration (lower } \\
\text { side), and title, } \\
\text { logo, and menu in } \\
\text { the left front side. }\end{array}$ \\
\hline & & $\begin{array}{l}\text { Direct opening } \\
\text { Glass opening }\end{array}$ & & $\begin{array}{l}\text { : Additional title an } \\
\text { : Directly painted } \mathrm{v} \\
\text { : Additional menu } \\
\text { : Additional banner }\end{array}$ & $\begin{array}{l}\text { d logo } \\
\text { isual identity } \\
\text {. }\end{array}$ \\
\hline \multicolumn{2}{|c|}{ Conclusion } & \multicolumn{2}{|c|}{$\begin{array}{l}\text { Every booth has openings, either direct } \\
\text { opening or glass opening. Some booths } \\
\text { have openings in all sides (front-back- } \\
\text { sides), while the other have three sides } \\
\text { (front, sides) and two sides (front and } \\
\text { left/right side). }\end{array}$} & \multicolumn{2}{|c|}{$\begin{array}{l}\text { All booths in this study possessed visual } \\
\text { identities, whether in the form of name and } \\
\text { logo, direct painting, menu list, or banner. } 6 \\
\text { out of } 10 \text { booths used name and additional } \\
\text { logo, } 2 \text { of } 10 \text { booths used directly painted } \\
\text { illustration, } 5 \text { of } 10 \text { booths used additional } \\
\text { banner, and } 2 \text { of } 10 \text { booths used additional } \\
\text { menu lists. }\end{array}$} \\
\hline
\end{tabular}


As shown in Table 1, one of the attractive factors of the booth is its appearance. The most prominent outer form is the main opening on the front side of the booth, which is used as a medium to perform the transaction. The side and back openings function for circulation.

Regarding the outer form, it could be concluded that all booths have an opening, either a direct opening or indirect opening (made of glass). Some booths have openings on all sides (frontback-sides), while the other has three sides (front, sides) and two sides (front and left/right side). Two booths used both direct and glass openings (i.e., Kebab Tunisia and Kopi Milenial booths), while other booths used direct openings.

Almost all booths have the same opening form and system, except Kebab Tunisia and Kopi Milenial. The form of Kebab Tunisia container booth is different from the other booths because its form is similar to a cart with front, left, and right glass openings and direct openings in the back. Meanwhile, Kopi Milenial booth was different from others since it applied both direct and glass openings that allow customers to watch the coffeemaking process, thus increase the aesthetic value of the booth.

To conclude, the main booth opening is located in the front, while the secondary openings are in the left, right, and back sides of the booth. These openings could be made in more attractive form to attract customers' attention.

In addition to openings in the outer form, another interesting point is related to the visual identity of the booth. Visual identity, or brand identity, is an identity to distinguish a brand from another. American Marketing Association (2004) defines a brand as a name, design, symbol, or any other feature that distinguishes a product or a service of a provider from that of other providers (Borislava Stoimenova). Corporate visual identity plays important role in presenting itself to the customers (van den Bosch et al., 2005)

This study found that each booth had its own character and identity in accordance with its product.

Table 2 Analysis of the effect of the product and visual identity on color selection

\begin{tabular}{|c|c|c|c|c|}
\hline $\begin{array}{l}\mathbf{N} \\
\mathbf{0}\end{array}$ & Product & Association & Color & Description \\
\hline 1. & & & & $\begin{array}{l}\text { The color applied in the booth } \\
\text { is in harmony with the color in } \\
\text { logo, but did not represent the } \\
\text { color of the product being sold }\end{array}$ \\
\hline 2. & & & & $\begin{array}{l}\text { The color applied in the booth } \\
\text { is in harmony with the product } \\
\text { Black represents black kebab, } \\
\text { yellow represents the flatbread } \\
\text { and red represents the meat. }\end{array}$ \\
\hline 3. & & & & $\begin{array}{l}\text { The color applied in the booth } \\
\text { is consistent with the logo, } \\
\text { product, and the packaging. } \\
\text { Yellow represents the color of } \\
\text { noodle, and white represents } \\
\text { the color of the noodle box. } \\
\text { Black represents the logo } \\
\text { outline. }\end{array}$ \\
\hline
\end{tabular}




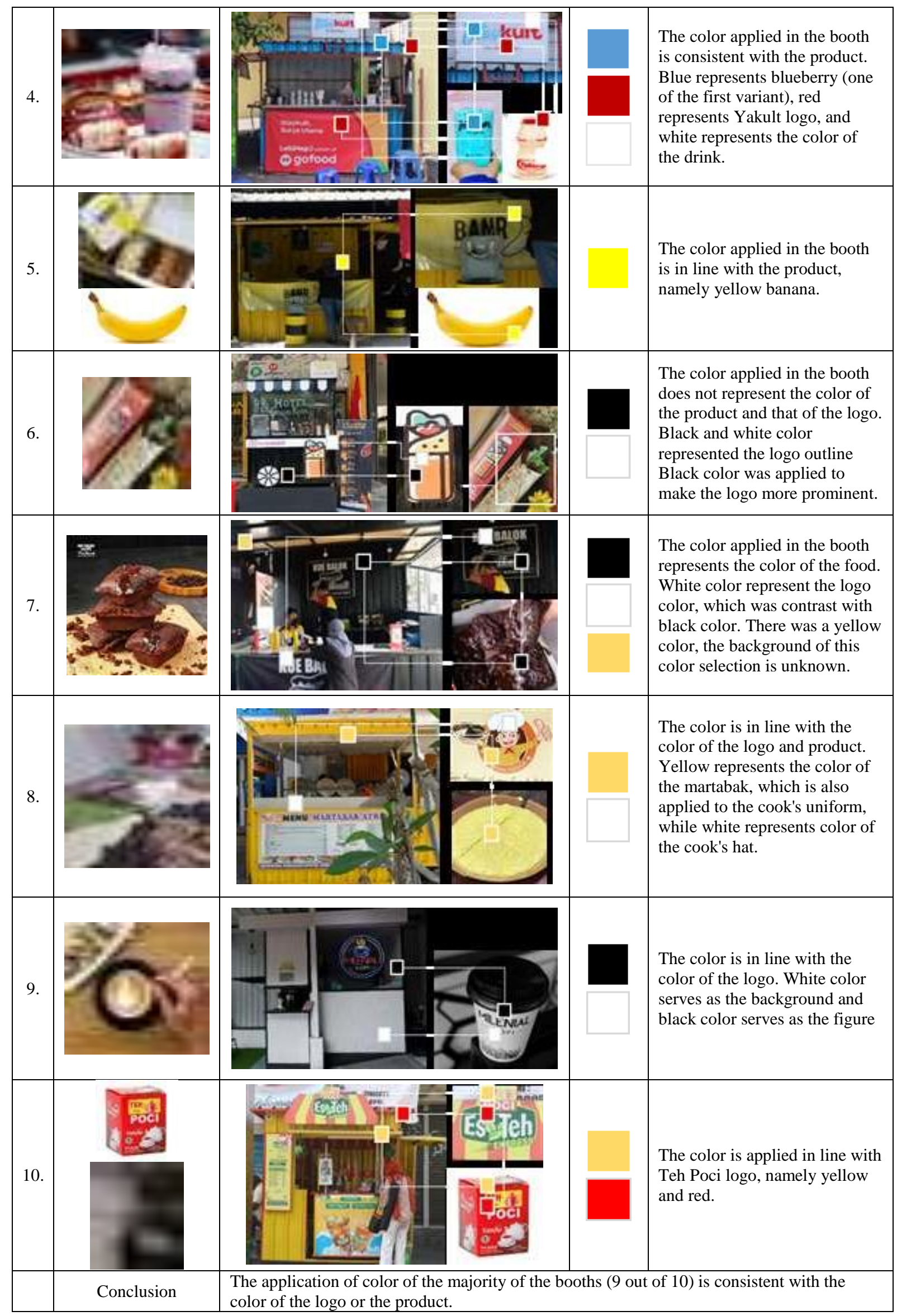


As displayed in table 2, all booths had visual identities, whether in the form of name and additional logo, direct painting, menu list, or banner. 6 out of 10 booths used name and additional logo, 2 of 10 booths used directly painted illustration, 5 of 10 booths used additional banner, and 2 of 10 booths used additional menu lists.

Banner was considered a less attractive visual identity because it was not properly attached, as found in 3 out of 5 booths (i.e., Staykult, Banris, and Kue Balok Parikesit).

The most attractive visual identity was found in booths that exhibited brand name and logo as the identity of the product and the booth. Illustration of the food that was sold in the booth could attract the customers' attention. In addition, the displayed menu list also ease the customer to choose what they want. Booths that applied these three aspects were Teh Poci and Mimasoyong booths.

As shown in table 2 figure 3 and 10, the visual identity of the brand, logo, illustration, and menu list does not only highlight the identity of the product but also add more attractiveness, compared to booths that used only one or two visual identities. It could be concluded that the visual identity of a booth may affect the form of the booth, and a more attractive booth is possible to draw more attention.

The application of color of the majority of the booths (9 out of 10) is consistent with the color of the logo or the product. Kebab Tunisia is the booth in this study which color application is not in harmony with the product and the logo. The color of Kebab Tunisia color is brownish yellow, red, green, yellow, whereas the booth was colored in black and white. These colors were possibly chosen to make the kebab illustration more prominent, where black color was used as the background and logo as the figure. Black and white color were also found in the logo outline.

Moreover, three booths applied colors that are in line with their brand logo but are not in harmony with the product they sold (i.e., Cireng Ginuek, Kopi Milenial, and Teh Poci booths).

The majority of visual identities in booths that were represented by the logo, product, and color application were interrelated. Their visual identity exhibits strong character and identity that is consistent with the product they sell. 7 of 10 booths could be easily recognized by customers, they were Kebab Turki Baba Raffi, Mimasoyong, Banris, Kebab Tunisia, Kue Balok Parikesit, Kopi Milenial, and Teh Poci. The identity of these booths could be easily identified since they clearly show the illustration of the product. Regarding color application, 9 of 10 booths applied colors according to their logo and product color. In other words, these booths were built based on the identity of the product and represented the product. It is done to make customers easier to recognize the product.

\section{Analysis of space function and organization}

Container-booth provides more functions compared to the conventional street food cart. While the majority of conventional street food stall needs additional spaces, e.g., dishwashing area or storage, Container booth does not need additional temporary space to support the sellers' activities. The following table displays types of activities done within the container booth, thus showing types of areas needed within the container booth.

Table.3 Activities and area that accommodates them

\begin{tabular}{|c|l|l|}
\hline NO & \multicolumn{1}{|c|}{ Activity } & \multicolumn{1}{|c|}{ Space/area } \\
\hline 1. & Opening and cleaning the booth & Area to store the cleaning equipments \\
\hline 2. & Arranging the equipments & Place/area to put the utensils and food materials \\
\hline 3. & Preparing the materials & Place/area for preparation \\
\hline 4. & Processing food & Processing area \\
\hline 5. & Preparing ice cube & Place/ area to store ice cube \\
\hline & Serving customers (cooking/preparing a drink, & $\begin{array}{l}\text { a. Place/area to cook/prepare drinks } \\
\text { b. Place/ area to package food/drink } \\
\text { c. Transaction area }\end{array}$ \\
\hline 7. & packaging, and doing transaction) & Rest area \\
\hline 8. & Praying & Prayer area \\
\hline 9. & Dish washing & Dish washing area \\
\hline 10. & Cleaning up the booth & Area to store the cleaning equipments \\
\hline 11. & Bringing the materials home & - \\
\hline 12. & Closing the booth & - \\
\hline
\end{tabular}

As shown in Table 3 above, the activities done in these booths were similar. The difference could be found in booths that require food preparation activities such as Banris, Kebab Tunisia, Kue Balok Parikesit, and Martabak Spektakuler Asia and drink preparation process like 
Staykult and Teh Poci. Another difference is related to the praying area, while Teh Poci booth allows sellers to perform prayers within the booth, other booths do not.

Based on the data related to the activities above, space/area that is required to accommodate them could be identified. The following are required places for the activities mentioned above.

These booths could be divided into two types, food booth and beverage booth. Regarding the food booth, there are some areas related to food preparation activities. Areas and functions of the food booth include equipment storage (place to store cleaning equipment), tools and ingredient storage, transaction area, cooking area, packaging area, rest area, and dishwashing area. The areas and functions of the beverage booths were similar to food booths. The difference lies in cooking area and ice cube storage. Out of these activities, there is one additional activity in Teh Poci booth, namely praying.

The areas and functions within these booths were arranged based on the sellers' needs. Cleaning equipment storage was in the form of a cabinet located below the transaction/packaging/foodprocessing area. Since it is not necessary to display the cleaning equipment, they were put in areas that could not be seen by customers. As shown in majority of the booths, the broom was put outside the booths near the door. Utensils and ingredients were stored in two different storages.

Big utensils and some ingredients (e.g, chopped vegetables, topping, syrup) were put near to transaction area. They were put near the transaction area to show the customers the equipment they use to make the food/drink product. In addition, the display of this equipment can also add more aesthetic values. Small equipment (e.g., packaging box, cup, straw) were put in the lower cabinet, except Teh Poci that put them on a rack on the booth wall.

Area for cooking, packaging, and transaction (food booth) or preparing, packaging drink, and transaction (beverage booth) were adjacent because these activities were done in sequence. Ice cube storage (in the beverage booth) was located near the preparation area to make it easy to access.

The rest area was located in the center of the booth, which was in the form of a chair for the seller. In the larger booth, e.g., Cireng Ginuek booth, there was an area where sellers can lie down. In other booths, the rest area was only in the form of a chair for the sellers. In Teh Poci booth, although the rest area is not too large, it was also used to pray.

To conclude, container booths selected in this study had been able to accommodate all commercial purposes needed by the sellers. These booths consisted of some areas that possess certain functions. The first area was the transaction area, it functions to perform transactions between sellers and buyers, some of this area was also optimized to display the ingredients that add more aesthetic value and attractiveness. The second area was the

cooking area/ drink preparation area that functions to process the product being sold. The third area was the packaging area, located between the cooking and transaction area, which functions to pack or to add topping to the product. The fourth area was storage, this area is divided into three sections, namely storage for ingredients stock, storage for reserved utensils (e.g, cup, straw, box stocks), and storage for cleaning equipment such as dust cloth and cleaner spray. In beverage booths, there is storage for ice cubes. This storage is usually made of plastic (as found in Staykult and Teh Poci) or stainless steel (as found in Kopi Milenial). The fifth area was the rest area for sellers. In some booths, the rest area is large enough for seller to lie down, while in other booths sellers can only sit down on a chair. In Teh Poci booth, the rest area is also utilized to perform prayers. The last area is the dishwashing area. Out of 10 booths, only one booth, that provides an indoor dishwashing area, namely Kopi Milenial booth.

These booths also have some areas to accommodate customers' activity. These areas are the transaction area and waiting area. In the transaction area, customers can order the food/drink and receive their order. Meanwhile, in the waiting area, located in front of the booth, some chairs are available for customers. Furthermore, in the transaction and queue area, the opening also functions as a shelter.

It is also necessary to see the spatial organization inside the container booth by seeing the booth layout. Spatial organization is an important aspect of interior design. A good space is arranged following the users' activity needs. Container booths in the present study have different layouts and spatial organizations, depending on the users' (i.e., seller) activities.

Space in architecture is divided into three dimensions (length, width, and height) which are limited by lower, side, and upper elements as the boundary of the space. Meanwhile, in the interior design field, it is divided into several parts including floor, wall, ceiling, and supporting elements such as furniture. D.K. Ching (1996) mentions five types of spatial organization, namely: (1) centralized organization, (2) Linear organization, (3) Radial organization, (4) clustered organization, and (5) grid organization. The spatial organization of these container booths could be seen from the arrangement of the furniture and the activities involving this furniture. 
Table 4 Spatial organization in each Booth

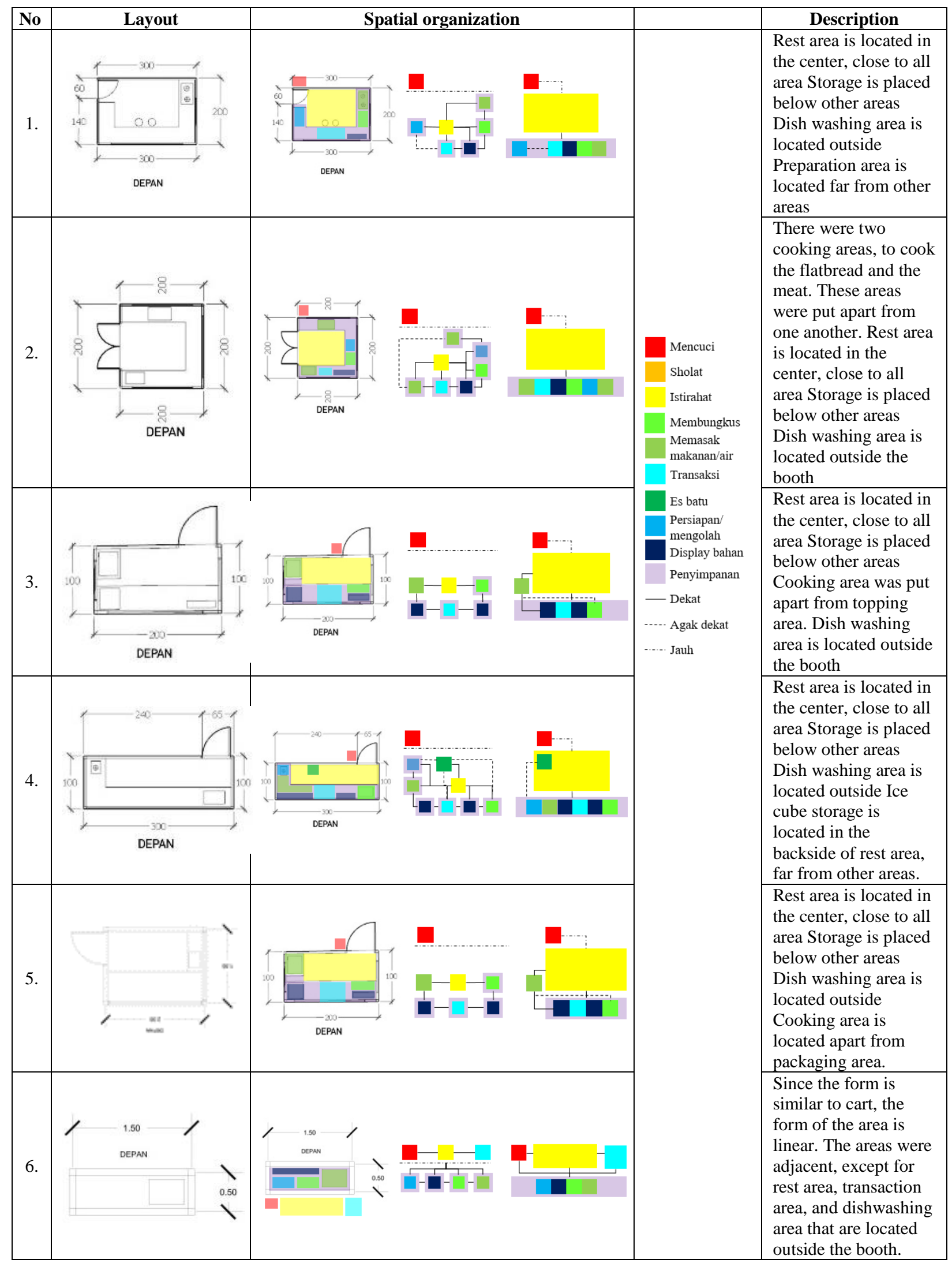




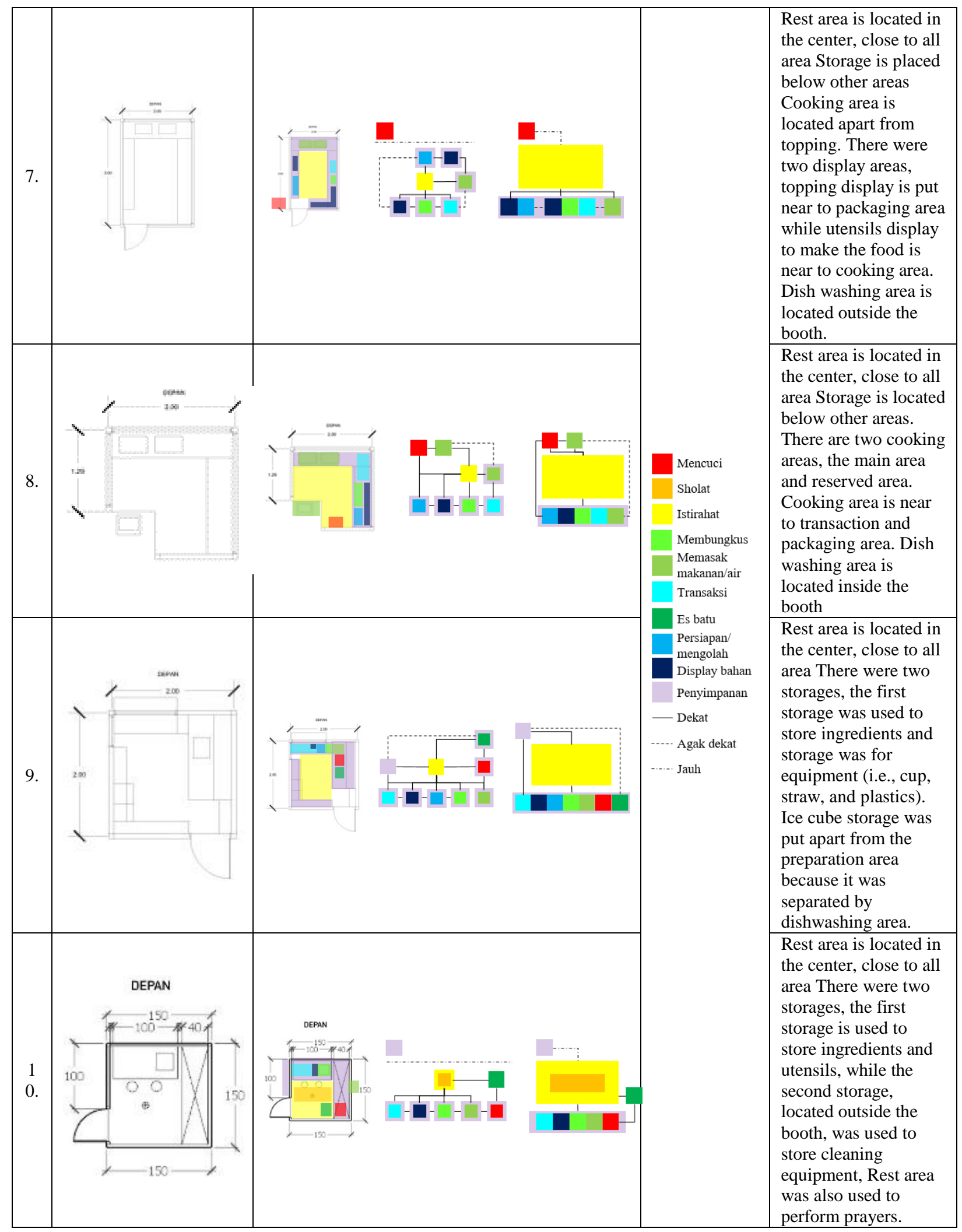


The analysis showed that each booth has different spatial organizations. However, the organization pattern is similar. The booth consisted of the transaction area, cooking area, packaging area, display area, storing area, rest area, preparation area, and dishwashing area. In Teh Poci booth, the rest area was also used to perform prayers. The similarity of these booths lies in their rest area that is located in the center of the booth and the relationship and sequence of activities between one and another area, as transaction area that is located near to cooking/ drink preparation area and packaging/topping area. In several booths, the transaction area, cooking area, and packaging area are arranged nonadjacent. However, since the booth is not too large, such an arrangement does not bother the sellers' activity. Another similarity was also found in the storage where it is in the form of cabinet located below other areas. In Kopi Milenial and Teh Poci booths, the storage was in the form of a wall rack located above other areas. In most of the booths, dishwashing activities are done outside the booth, only three booths provided a dishwashing area inside the booth, namely Martabak Atria, Kopi Milenial, and Teh Poci booths. Martabak Atria and Kopi Milenial used sink for dishwashing activities since they connected to water supply system, while Teh poci uses two buckets, one for clean water and one for wastewater. In Teh Poci booths, rest area is also used for praying area although the space is not large enough to perform prayers $(1 \mathrm{~m} 2)$.

The spatial organization is adjusted to the needs of the product. There were three spatial organization patterns found in these booths. The first pattern was found in booth selling foods in which the raw ingredients were brought from home and cooked in the booths. They were Cireng Ginuek, Mimasoyong, and Kue Balok Parikesit booths. The second pattern was found in booths selling food that is processed directly in the booths, they were Kebab Turki Babah Raffi, Banris, Kebab Tunisia, and Martabak Atria booths. The third pattern was found in booth selling beverages, i.e., Staykult, Kopi Milenial, and Teh Poci booths.

In booths that applied the first pattern, the similarity lies in the adjacency of the cooking area and packaging area that are near to topping display. Among booths applying this pattern, only Mimasoyong booth put the cooking area apart from the packaging area. While Cireng Ginuek and Kue Balok Parikesit booths have an area to process raw ingredients, Mimasoyong does not have such area since its ingredient was instant noodles. To conclude, the first spatial organization pattern is ideal for a booth that does not require raw ingredients processing activities.

From the spatial organization pattern mentioned above, two options are available, first, without a sink (dishwashing activities are done outside the booth) and second, with a portable sink (dishwashing activities are done inside the booth). These options emerge from the dishwashing activities that could be done inside or outside the booth. Using this pattern, the cooking, packaging, display, and transactions area are arranged adjacently following the sequence of the seller's activities.

In this pattern, the left side of the transaction area is used as a display area. This display area is used to exhibit the product to the customers, for instance, Cireng Ginuek and Mimasoyong can display their packaged raw ingredients in this area. Using these options, there is a blank space that can be used as a secondary processing area. In option 2 (with sink), a portable sink could be put near to the secondary processing area to facilitate dishwashing activities. Food preparation and dishwashing areas are put in the backmost.

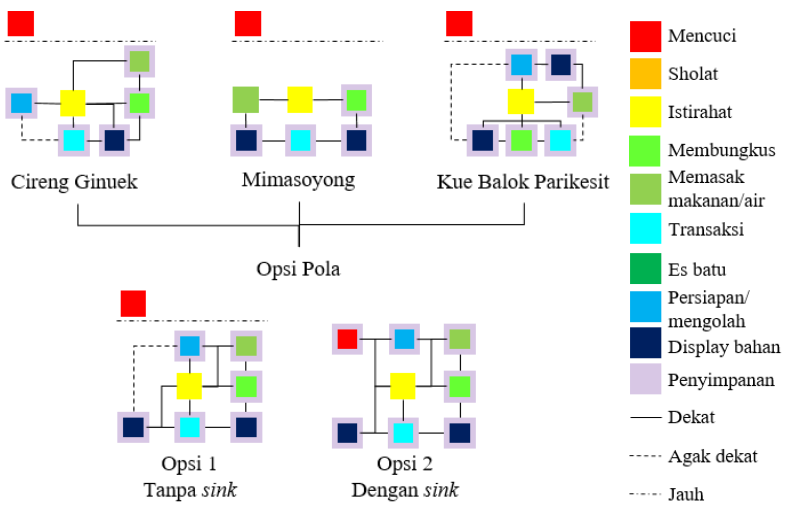

Figure 1. Spatial organization pattern food booth without processing stage and the ideal organization (Source: research team, 2020).

Regarding the second spatial organization pattern, the similarity lies in the presence of the preparation area. In Kebab Baba Rafi and Banris booths, the processing area was located near to the cooking area, while in Kebab Tunisia and Martabak Spektakuler Atria, the processing area was located near to display area. The sequence of the activities is receiving the order from customers, preparing the order, cooking order, packaging order, and giving the order to customers. Accordingly, the organization pattern of these four booths is arranged in accordance with the activities. In this second pattern, dishwashing activities were also done. Similar to the first pattern, dishwashing activities could be done inside or outside the booth.

Following the description above, there are four pattern options, the first two patterns were pattern with and without sink, while the other two patterns are patterns where packaging and processing activities are put in the same area, with or without sink. Option 1 and 2 are based on these four booths. The transaction area is located near to 
display area that is adjacent to the packaging and preparation area. The preparation area is adjacent to the cooking area. Meanwhile, regarding options 3 and 4 , the difference lies in packaging and preparation activities that are done in one area to improve efficiency when accessing ingredients and topping in the display area. The sink (option 2 and 4) is located in the backmost of the booth since the customers do not need to watch dishwashing activities.

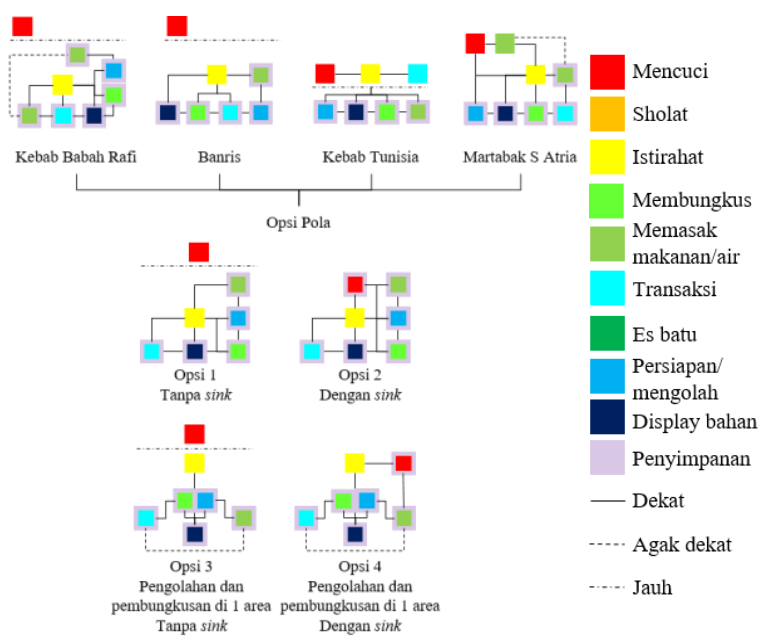

Figure 2. Spatial organization pattern food booth with processing stage and the ideal organization (Source: research team, 2020).

The third pattern was found in beverage booths, i.e., Staykult, Kopi Milenial, and Teh Poci booths. Similar to the food booth, the spatial organization in these booths also depends on the type of product. All these beverage booths have the same needs, the difference is the distance between one area to another, which depends on the character of the product. In the Staykult booth, there were two display areas, the first area was to show the ingredient (e.g., Yakult and condensed milk) while the second area was to exhibit the equipment (e.g., thermos and cup sealer). The drink preparation area is located apart from the packaging area since they were separated by the transaction area. There was an area to boil water and ice cube storage near the preparation area. In Staykult booth, the dishwashing area is located outside the booth, there was a bucket to dispose the excessive drink.

Different from Staykult booth, Kopi Milenial has a coffee maker that is put in the display area so that the customer can watch the process, while the packaging and topping areas were not displayed. The packaging area is adjacent to the coffeemaking area. Based on such organization, the order was transaction area, coffee-making area (displayed), packaging area, preparation area, dishwashing area, and ice cube storage. The preparation area was apart from ice cube storage since they were separated by the sink. Meanwhile, in Teh Poci booth, the preparation and tea-making activities are located in the same area. This area is adjacent to the packaging and display area. Next to these areas were ice cube storage, while the dishwashing area is located below the ice cube storage.

These booths had different spatial organization options depending on their needs, which could be divided into two types, booth with sink and booth without sink. This spatial organization pattern applies to booths with similar characteristics. In Staykult booth, the organization pattern is almost similar to the original pattern, the difference lies in the order of the area that is arranged based on the sequence of the activities. The ideal form is that the packaging/topping area is put adjacent to ice cube storage.

The preparation area (i.e., boiling water) is located in the back area near the drink-making area. In Kopi Milenial booth, the ideal spatial organization pattern is almost similar to the original pattern. The difference lies in the display area that exhibits various ingredients and toppings so that the coffee-making and packaging activities are done in one area. The preparation area is located adjacent to the ice cube storage. In Teh Poci booths, the ideal organization is also similar to the original pattern, the difference is that the display is located near to transaction area and apart from other areas because the displayed product is various Teh Poci products, not toppings.
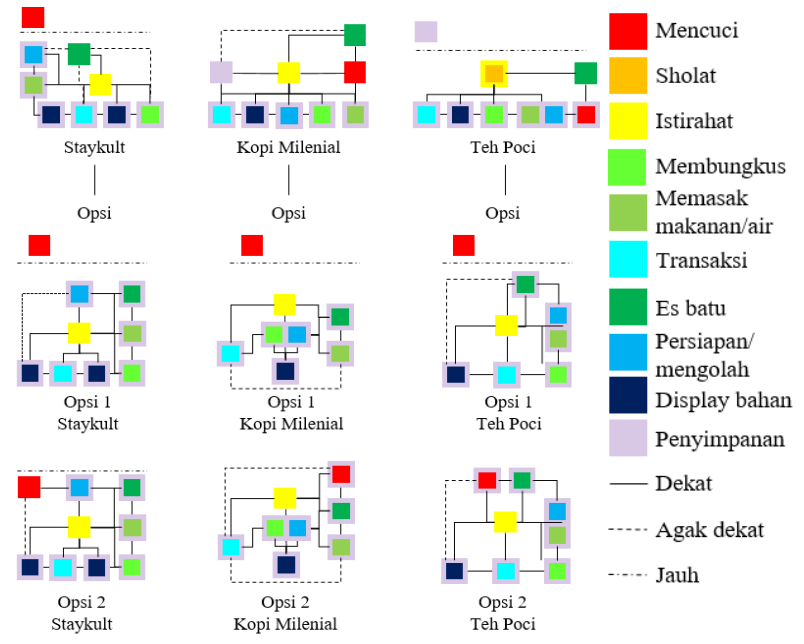

Figure 3. Spatial organization pattern of beverage booth and the ideal organization (Source: research team, 2020).

These booths had different spatial organization options depending on their needs, which could be divided into two types, booth with sink and booth without sink. This spatial organization pattern applies to booths with similar characteristics. In Staykult booth, the organization pattern is almost similar to the original pattern, the difference lies in the order of the area that is 
arranged based on the sequence of the activities. The ideal form is that the packaging/topping area is put adjacent to ice cube storage. The preparation area (i.e., boiling water) is located in the back area near the drink-making area. In Kopi Milenial booth, the ideal spatial organization pattern is almost similar to the original pattern. The difference lies in the display area that exhibits various ingredients and toppings so that the coffeemaking and packaging activities are done in one area. The preparation area is located adjacent to the ice cube storage. In Teh Poci booths, the ideal organization is also similar to the original pattern, the difference is that the display is located near to transaction area and apart from other areas because the displayed product is various Teh Poci products, not toppings.

In Teh Poci booth, there is an additional activity in the rest area (i.e., praying). Prayer activity could be properly performed if the rest area is large enough, however, in Teh Poci's case, the area was only $1 \mathrm{~m} 2$, which is less suitable to perform prayer. A praying area could be added if the rest area is approximately $1,5 \mathrm{~m} 2$. Space is organized in accordance with the needs and the sequence of the activities. Based on the analysis of 10 selected booths, three spatial organization patterns were found. The first pattern is the foo booth without preparation process, the second pattern is the food booth with preparation process, and the third pattern is beverage booth. In each pattern, the storage is in the form of a cabinet that is located below other areas or a wall rack.

\section{CONCLUSION}

Out of 10 container booths in Surakarta, seven booths exhibit aesthetic aspects and harmony with the visual identity of the products. They were Kebab Turki Baba Raffi, Mimasoyong, Banris, Kebab Tunisia, Kue Balok Parikesit, Kopi Milenial, and Teh Poci booths. The identity of these booths could be easily identified since they clearly show the illustration of the product. Regarding color application, 9 of 10 booths applied colors according to their logo and product color. In other words, these booths were built based on the identity of the product and represented the product. It is done to make customers easier to recognize the product. The majority of visual identities in booths, represented by the logo, product, and color application, are interrelated. Their visual identity exhibits strong character and identity in line with the product they sell.

These booths consisted of several areas, namely (1) transaction/ display area; (2) cooking/ processing area; (3) packaging area; (4) storage; and (5) rest area. The spatial organization is adjusted to the needs of the product. There were three spatial organization patterns found in these booths. The first pattern was found in food booths in which the raw ingredients were brought from home and cooked in the booths. They were Cireng Ginuek, Mimasoyong, and Kue Balok Parikesit booths. The second pattern was found in the food booth where the food is prepared directly in the booth, they were Kebab Turki Babah Raffi, Banris, Kebab Tunisia, and Martabak Atria booths. The third pattern was found in beverage booths, i.e., Staykult, Kopi Milenial, and Teh Poci booths. These booths had different spatial organization options depending on their needs, which could be divided into two types, booth with sink and booth without sink. The space is organized in accordance with the activities. Based on the analysis of 10 selected booths, three spatial organization patterns were found. The first pattern is booth without food preparation process, the second pattern is booth with food preparation process, and the third pattern is beverage booth. In each pattern, the storage is in the form of a cabinet that is located below other areas or wall rack. Container booth holds advantages since it could be easily arranged and allows more aesthetic aspects to be put on it. Some symbols (i.e., form and color) are consistent with the product being sold. This consistency may attract customers' attention since it could be recognized more easily, something that is difficult to be done using a conventional cart. In addition, the larger space provided by the container booth allows the seller to arrange the space to best suit their activities.

\section{REFERENCES}

Eggi Septianto, Handoyo Dwi P., Arief Rahman H., Dimastian Susetyo. 2015. "Aplikasi Modul Kontainer Terhadap Desain Ruang Pada Bangunan Poli Gigi Dan Taman Baca Amin Di Batu, Malang." Reka Karsa 3(1):1-11.

Hignasari, L. Virginayoga, and Eka Diana Mahira. 2018. Optimization Of Goods Distribution Route Assisted By Google Map With Cheapest Insertion Heuristic Algorithm (Cih). Sinergi.

Maria Valenciana Utari Prajogo, and Purnama E.D. Tedjokoesoemo. 2015. Perancangan Interior Kontainer Sebagai Sarana Edukasi Di Rusun Sombo Surabaya.

Putra, Kharrel Dwi. 2016. Studi Pemanfaatan Kontainer Sebagai Rumah Hunian Sementara Pasca Bencana, Proceeding Seminar ACE 7(2):1-16.

Norris, Brodie. 2015. Build Your Own Shipping Container Home The Beginner's Guide Knowledge dynamics in localized communities: coworking spaces as microclusters, Ignasi Capdevila (HEC Montréal)

Suryajaya, Martin. 2016. Sejarah estetika: era klasik sampai kontemporer. Gang Kabel, Indie Book Corner.

Stoimenova, Borislava. Visual Brand Identity Design. Academia Edu. 
https://www.academia.edu/36218368/VISUAL_ BRAND_IDENTITY_DESIGN: 346-353.

Van den Bosch, A. L. M. (2005) Corporate visual identity management:current practices, impact and assessment, Printed by Haveka bv.

D. K. Ching, Francis (1996). Architecture; Form, Space, And Order. Cetakan ke - 6. Jakarta. Penerbit Erlangga.

Aprilia S Andyna. 15 October 2015. Koran Sindo)(rhs) Tren Hunian Compact yang Semakin Berkembang. Accessed 20 November 2020. https://economy.okezone.com/read/2015/10/15/4 70/1232201/tren-hunian-compact-yang-semakinberkembang

Hamsa, April. 2016. Eco and Compact Living, gaya hidup masa sekarang yang memberi value lebih pada kehidupan kaum urban. Accessed 21 January 2020. https://keluargahamsa.com/ecoand-compact-living/

Setiyaningsih, Wahidin (18 September 2019). Revitalisasi trotoar di Jakarta: Manjakan pejalan kaki atau PKL?. Alinea.id. accessed 20 November 2020.

https://www.alinea.id/nasional/revitalisasitrotoar-manjakan-pejalan-kaki-atau-pklb1XmF9nwZ 